\title{
Estimating the Impact of EU Membership on United Kingdom's Export by Using Gravity Model
}

\author{
Elena Makrevska Disoska, Ph.D. ${ }^{1}$, Katerina Toshevska-Trpchevska, Ph.D. ${ }^{2}$
} Irena Kikerkova, Ph.D. ${ }^{3}$, Jasna Tonovska, M.Sc. ${ }^{4}$

Received: 01.07.2021

Available online: 20.12 .2021

\begin{abstract}
After a year from the formal UK withdrawal from the EU, there are still different opinions about the potential economic impact of Brexit. This paper gives a detailed overview of the trade profile of UK and explores the determinants of United Kingdom's export. We apply the gravity model to estimate the aggregate benefits of EU membership or the reversed, lost (foregone) benefits from leaving the EU. We measure the influence of GDP, distance, population, the EU membership, and signed free trade agreement with the trading partners on UK's export as a dependent variable. The analysis includes data for 70 UK trading partners in a period of 48 years (from 1973 to 2020) since Great Britain become EU member.

The results show that UK's export is directly proportional to trade partner's GDP and inversely proportional to distance. In order to estimate the average benefit due to EU membership, we estimated subsequent equations with different time periods. The coefficient decreases and becomes negative as we shorten the time periods, proving that the average trade advantage due to EU membership diminishes over time. According to the economic theory of regional integration, it is expected that the coefficient increases due to many rounds of enlargement, especially the biggest one in 2004 as well as due to the introduction of the Euro. On the contrary, as we shorten the time periods in the analysis, we obtained increasing coefficient for the variable free trade agreements. This confirms

1 Associate Professor at the Ss. Cyril and Methodius University in Skopje, Faculty of Economics-Skopje, e-mail address: elenam@eccf.ukim.edu.mk

2 Associate Professor at the Ss. Cyril and Methodius University in Skopje, Faculty of Economics-Skopje, e-mail address: katerina@eccf.ukim.edu.mk

3 Full-time Professor at the Ss. Cyril and Methodius University in Skopje, Faculty of Economics-Skopje, e-mail address: irena@eccf.ukim.edu.mk

4 Teaching and Research Assistant at the Ss. Cyril and Methodius University in Skopje, Faculty of EconomicsSkopje, e-mail address: jasna.tonovska@eccf.ukim.edu.mk
\end{abstract}


that trade exchange within FTA has significantly higher effect on United Kingdom's export in comparison with trade within EU.

Keywords: United Kingdom's export, EU membership, free trade agreements, gravity model, Brexit.

JEL: F15, F17, C33

\section{Introduction}

The United Kingdom was member of the EU for 47 years. It acceded the Union in 1973 and was officially the first member state that left the EU on 31 January 2020. During the UK's membership two referendums were held on the issue of its membership. The first referendum was held in 1975, and $67 \%$ of the people of the United Kingdom voted against leaving the EU. The second one was held in June 2016 and the results were in favor of leaving the EU (51.9\% of the voters). At the end of January 2020 , the country officially left the EU.

The United Kingdom has always been in favor of intergovernmental cooperation in the EU and therefore never became part of the Eurozone, Schengen zone, Charter of Fundamental Rights, The Fiscal Stability Treaty and many more European projects. The political stance within the United Kingdom that opposed the idea of EU was intensified after the financial crisis in 2008 and especially at the beginning of the migrant crisis in 2014. The UK was a top destination for migrants from the poorer EU states and the fear of refugees from Syria, Africa and the Middle East further intensified skepticism among voters and politicians.

Agreement on the terms of the future relationship between EU and the United Kingdom was reached at the end of 2020, by signing the EU-UK Trade and Cooperation Agreement (the Agreement or TCA) on 30 December 2020. Its provisional application as of 1 January 2021 establishes the terms of the new relationship between the EU and the UK, following the end of the transition period established by the Withdrawal Agreement (WA).

Following the exit from the EU, the UK's relations with its trading partners in and outside the European Union has changed. There are two considerations about the impact of Brexit on the trade relations of UK with the rest of the world. One view is that Brexit significantly weakens Britain's position in world trade. The country will cease to enjoy EU's collective bargaining power, considering that the EU is the world's largest trading block and has considerable power in international trade negotiations. Brexit means the UK's withdrawal from the EU customs union and common external customs regime of the European Union. In theory, the UK could participate in the customs union as a non-EU country, following the example of Turkey. However, the British government has made it clear that they intend to leave the customs union of the EU.

The second opinion is that Brexit strengthens the international trade position of the United Kingdom. As a member of the European Union, the UK was not' able to negotiate bilateral trade agreements with the rest of the world partners. Also, the 
UK believes that the substantially overprotected agricultural policy in favor of the continental European farmers and other protectionist lobbies prevented the EU from concluding significant trade agreements. Leaving the EU will allow Britain to become a global "beacon" of free trade, concluding strong trade liberalization agreements with developed countries (Australia, New Zealand, United States) and emerging economies (Brazil, China, India).

Proponents of Brexit further argue that an independent Britain could better adapt to the international political environment. The withdrawal of Trump's administration from TPP (Trans-Pacific Partnership) and the attacks on NAFTA (North American Free Trade Agreement) signal American hostility to regional trade agreements. There are very low prospects for a pact between the EU and the US under the TTIP (Transatlantic Trade and Investment Partnership), and this creates a niche for a bilateral trade agreement between the UK and the US.

The UK is among the top 10 in the world exporters and importers of trade in goods. Within the category of export of goods, the UK ranks 4th in air product exports, 6th in pharmaceuticals and 6th in motor vehicles. In 2019, the UK had $\$ 226.11$ billion deficit in trade in goods. But this trade deficit in goods was largely offset by a surplus of $\$ 132.61$ billion in services-related trade, reflecting the UK's position as the world's second leading exporter of services. In the services category, business and professional services represent the largest share in the export of services in the UK, followed by financial services and copyrights and licenses - global industrial services in which the UK has important competitive advantages. Trade in services of the United Kingdom is geographically more widespread than the trade in goods, with 37.2 per cent of UK services exports going to the EU versus $43.8 \%$ of UK exports of goods going to the EU (OEC, 2019).

Seven of UK's top 10 global trading partners are countries from the EU. But with the partial exception of Germany, the growth rates of British trade with other EU countries are modest (except for Poland). The fastest growing export markets in the United Kingdom are outside the European Union: Switzerland, South Korea, Turkey, Saudi Arabia, China, and United Arab Emirates. However, free trade agreements between developed and emerging economies based on mutual concessions on agriculture and services have proven extremely difficult to complete.

After the introduction, in the second chapter we provide literature review on the application of gravity models on United Kingdom trade. In the third section we explain the specification of the model and in the fourth section we present the results. The final section, fifth, concludes.

\section{Literature review}

The consequences of Brexit on the UK economy are investigated in various institutional and academic studies, which employ different scenarios for the trade arrangements in the 
post-Brexit period. The scenarios range from the baseline scenario of the UK remaining in the EU, to several intermediate scenarios such as FTAs, a customs union arrangement or membership in the European Economic Area, and to a WTO scenario, or a no deal scenario. The vast majority of studies conclude that Brexit will reduce economic growth - albeit to a varying extent. This chapter reviews the related body of research, in particular the choice of models and transmission channels considered, and how they relate to the magnitude of the estimated economic consequences of Brexit.

One common approach in the Brexit-related research is to use gravity models, in order to first estimate how changes to trade barriers could affect trade flows and then feed these estimates into a model of UK and world economic activity. Campos and Timini (2019) develop structural gravity models with the aim of estimating how trade and migration between the EU and the UK are affected by Brexit. The analysis points to robust negative effects on migration flows for the UK and drop in the mutual trade flows by up to $30 \%$ (under the WTO scenario). Mulabdic et al. (2017) use partial equilibrium gravity model and conclude that the Brexit will reduce trade flows, with varying degree (between $-6 \%$ and $-28 \%$ ), depending on the scenario considered. Vandenbussche et al. (2017) extend the traditional gravity model by analyzing trade in value added. According to their estimations, the UK will experience a decline in value added production ranging from $1.2 \%$ of GDP under a soft Brexit and up to $4.5 \%$ of GDP under a WTO scenario, as well as significant job losses.

Many studies that have applied the gravity model have used one specific model - the National Institute Global Econometric Model (NiGEM). On the basis of this model, Berthou et al. (2019) find that, depending on the way the trade channel is modelled, UK GDP would decline by between $2 \%$ and $6 \%$ over the medium term under the WTO scenario. Previously, the NiGEM model is applied in the study by Kierzenkowski et al. (2016), who examine shortterm and long-term channels of transmission and conclude that Brexit is a major negative shock for the UK economy 5 . A comprehensive analysis of the robustness of the findings from the above mentioned study, as well as two other gravity-based studies, is provided by Gudgin et al. (2017).

Another way of modelling the global economy is by using a computable general equilibrium (CGE) model, which captures many industrial sectors, countries and regions of the global economy. By using New Keynesian DSGE model, Pisani and Caffarelli (2018) estimate that imposition of tariffs in the post-Brexit period would lead to noteworthy longterm costs for the UK economy (in the WTO scenario, real exports and real GDP decrease by about $7 \%$ and $2 \%$ respectively, and in the FTA scenario by $3 \%$ and $1 \%$ respectively). Cappariello et al. (2020) use multi-country, multi-sector general equilibrium model featuring GVCs to investigate the long-term effects of Brexit on trade, welfare and prices. Their estimates show a sizable decrease in UK's total trade, a drop in household disposable income (between $2.1 \%$ and $3.1 \%$ ) and an increase in price level. The general equilibrium

5 The short-term channels of transmission include tighter financial conditions and weaker confidence, higher trade barriers and restrictions on labor mobility, whereas long-term channels relate to the flows of capital, immigration and lower technical progress. 
trade model is implemented by Dhingra et al. (2017) as well, highlighting that the losses deriving from trade will be significantly linked to the productivity channel.

When estimating the economic effects of the Brexit, researchers take into consideration various transmission channels. Trade in goods and services is the most important transmission channel, since trade between UK and EU may become subject to tariffs and NTBs. In particular, models restricted only to the effects of trade report loss for the GDP of UK, ranging from $1.7 \%$ to $4.5 \%$. The inclusion of additional channels leads to more adverse impact on economic growth in the long term. According to Bisciari (2019), models that employ significant shocks in TFP and labor productivity, as well as models which combine several transmission channels, tend to generate the highest GDP losses for the UK (over 5 p.p. and, in some cases, over 10 p.p.). According to the authors, higher economic losses are also found in studies with reduced-form approaches, based on econometric estimates of trade-income elasticity, or in models with imperfect competition, in comparison to models with perfect competition.

To sum up, Brexit is generally seen to bring about negative consequences for the UK economy. Nevertheless, estimates of the Brexit losses vary, depending on the model and on the transmission channels that have been examined.

\section{Explanation of the model}

The United Kingdom is among the top 10 world exporters and importers of goods in the world. In order to explore the determinants of trade flows of the United Kingdom, we constructed a gravity model. This model is widely used to examine country-specific trade characteristics (Anderson and Wincoop, 2003). The analysis includes data on 70 trade partners of Great Britain in the period from 1973 to 2020. Britain's trading partners are selected according to the highest value of the country's export to the trading partners throughout the entire period under examination. Unfortunately, the database is unbalanced. For example, there are no data for Eastern European countries during 1980s and 1990s. Non existing countries are removed from the database (such as Soviet Union and Yugoslavia) since it was too risky to combine the data.

We have used OLS regression with fixed effects. We used the software EViews to estimate the model. By using the gravity model, we try to estimate the aggregate benefits of EU membership or the reversed, foregone benefits on leaving the EU.

To estimate the average benefit due to EU membership, we estimated subsequent equations with different time periods. We have estimated four specifications. In all four specifications $\mathrm{R}^{2}$ and the adjusted $\mathrm{R}^{2}$ are high, around $90 \%$, which suggests that the independent variables considerably explain the dependent variable: UK's export. In all equations we used the same variables. The dependent variable is export measured as FOB in million American dollars from Britain to each trading partner. The trade data is from the IMF's Direction of Trade Statistics for the period 1973-2020. 
The framework of the model is based on the analogy with the Newtonian theory of gravity reflecting the relationship between the intensity of trade between two partners, the size of their economies and the distance between them (Tinbergen, 1962; Bergstrand, 1985). The traditional gravity model successfully reproduces the volume of trade between trading partners using macroeconomic properties, such as GDP, geographic distance, and other related factors. Although there are different modifications of the model in terms of empirical specification (Helpman et al., 2008; Almog et al., 2019), we have used the basic model by constructing the following equation:

$$
\begin{aligned}
& \operatorname{LnTRADE} E_{i j t}=a i j+\alpha_{1} \ln \left(G D P_{i t}\right)+a_{2} \ln \left(G D P_{j t}\right)+\alpha_{3} \ln \left(\frac{\mathrm{GDPit}}{\mathrm{POPit}}\right)+a_{4} \ln \left(\frac{\mathrm{GDPjt}}{\mathrm{POPjt}}\right)+ \\
& a_{5} \ln \left(\frac{\mathrm{DISTANCEij} * \mathrm{GDPit}}{\text { World GDPt }}\right)+\beta_{1} E U+\beta_{2} F T A+e_{i j t}(1)
\end{aligned}
$$

In the selection of the independent variables we consulted the available academic literature, (HM Treasury analysis, IMF and OECD) and decided to include the most commonly used variables in the model: real GDP, GDP per capita, distance and two dummy variables: membership in EU and membership in FTA.

Table 1. Explanation for the used variables

\begin{tabular}{|l|l|l|}
\hline Name of the variable & \multicolumn{1}{|c|}{ Explanation } & \multicolumn{1}{c|}{ Source } \\
\hline EU & Member of the EU & Dummy variable \\
\hline FTA & Part of free trade agreement & Dummy variable \\
\hline Export & $\begin{array}{l}\text { Export, FOB in million American dollars from Unit- } \\
\text { ed Kingdom to each trading partner. }\end{array}$ & $\begin{array}{l}\text { IMF's Direction of Trade } \\
\text { Statistics } \\
\text { https://data.imf.org/regu- } \\
\text { lar.aspx?key=61013712 }\end{array}$ \\
\hline Log (DISTANCE) & Bilateral distances (in km) & CEPI's GeoDist database \\
\hline Log (GDP partner) & $\begin{array}{l}\text { Real GDP, in millions of 2020 international dollars, } \\
\text { converted using Purchasing Power Parities }\end{array}$ & $\begin{array}{l}\text { The Economic database, The } \\
\text { Conference Board }\end{array}$ \\
\hline Log (GDPUK) & $\begin{array}{l}\text { Real GDP of UK, in millions of 2020 international } \\
\text { dollars, converted using Purchasing Power Parities }\end{array}$ & $\begin{array}{l}\text { The Economic database, The } \\
\text { Conference Board }\end{array}$ \\
\hline $\begin{array}{l}\text { Log (GDP per capita, } \\
\text { partner) }\end{array}$ & $\begin{array}{l}\text { Real GDP, in millions of 2020 international dollars, } \\
\text { converted using Purchasing Power Parities divided } \\
\text { by Midyear population (thousands) }\end{array}$ & $\begin{array}{l}\text { The Economic database, The } \\
\text { Conference Board }\end{array}$ \\
\hline $\begin{array}{l}\text { Log (GDP per capita } \\
\text { UK) }\end{array}$ & $\begin{array}{l}\text { Real GDP, in millions of 2020 international dollars, } \\
\text { converted using Purchasing Power Parities divided } \\
\text { by Midyear population (thousands) }\end{array}$ & $\begin{array}{l}\text { The Economic database, The } \\
\text { Conference Board }\end{array}$ \\
\hline
\end{tabular}

Source: Created by the authors

The variable real GDP is calculated for the United Kingdom and for the respective trading partner. The variable GDP is presented in millions of international dollars, converted into Purchasing Power Parities. The source of the data is from the Conference Board database. 
The data for the variable population is also retrieved from the Conference Board database. Since the variable population if almost fixed through time, we divided the value of GDP with the population. The indicator shows the GDP per capita in the countries for the given period. We expected a positive coefficient, indicating that trade between two countries will be larger if per capita GDP is higher.

The results show that UK's export is directly proportional to trade partner's GDP and GDP per capita and inversely proportional to distance. Distance between trade partners is retrieved from the CEPII's GeoDist database. In order to make the variable dynamic over time, we multiply the distance with the GDP of the trading partner and divide with the value of the world GDP. If the distance between the two countries is higher, this implies higher transport costs. Hence distance is likely to have a negative impact on bilateral flows of trade.

Two dummy variables that we used in the model are constructed. Regarding the independent variables $E U$, is a dummy variable which equals 1 if the trading partner and UK are members of the European Union at the time $t$ and 0 otherwise. Therefore, if $E U[i, t]=1$, this is equivalent to a "joint /coinciding EU membership" of UK and country " $\mathrm{i}$ " in year " $\mathrm{t}$ ". In other words, $E U[i, t]=1$ indicates a situation of export from UK (one EU member state) to this country (another EU member state) in the respective year.

The variable FTA is a dummy variable which equals 1 if the origin country is a member of FTA with United Kingdom at time $t$.

\section{Explanation of the results}

In Table 2 we provide the results from the gravity model on UK's export. The results acknowledge that distance is statistically significant over United Kingdom's export but with negative influence. In all four time periods the coefficient is significant, negative and increasing, which suggests that increasing the mutual distance between the trade partners of UK has negative influence over UK's export.

The same analogy but with positive sign is acknowledged with the coefficient measuring UK trade partner's GDP. The coefficient is constantly increasing. This means that the bigger the GDP of the trading partners, the higher is the statistical significance of country's bilateral trade flows increment. Thus we confirm that Britain's greatest trading partners are countries with a significantly high GDP. Among the dominant trading partners of Britain are USA, Germany, China, Netherlands and France. They account for more than $46 \%$ of the total trade of Britain in 2019. 
Estimating the Impact of EU Membership on United Kingdom's Export by Using Gravity Model

Table 2. Results from the econometric model (OLS, panel data, fixed effects)

\begin{tabular}{|l|l|l|l|l|}
\hline \multicolumn{1}{|c|}{ Period } & \multicolumn{1}{|c|}{$\begin{array}{c}1973-2020 \\
\text { (48 years) }\end{array}$} & \multicolumn{1}{|c|}{$\begin{array}{c}\text { 1981-2020 } \\
\text { (40 years) }\end{array}$} & \multicolumn{1}{|c|}{$\begin{array}{c}\text { 1991-2020 } \\
\text { (30 years) }\end{array}$} & \multicolumn{1}{|c|}{$\begin{array}{c}\text { 2001-2020 } \\
\text { (20 years) }\end{array}$} \\
\hline No. of observations & 2967 & 2527 & 1977 & \\
\hline constant & $40.282^{* * *}$ & $\begin{array}{l}49.272^{* * *} \\
(9.184)\end{array}$ & $\begin{array}{l}38.605^{* * *} \\
(11.231)\end{array}$ & $\begin{array}{l}67.018^{* * *} \\
(11.801)\end{array}$ \\
\hline EU & $0.175^{* * *}$ & $0.184^{* * *}$ & $0.144^{* * *}$ & $0.053^{* *}$ \\
& $(0.052)$ & $(0.055)$ & $(0.058)$ & $(0.092)$ \\
\hline FTA & $0.308^{* * *}$ & $0.329^{* * *}$ & $0.299^{* * *}$ & $0.295^{* *}$ \\
& $(0.044)$ & $(0.047)$ & $(0.048)$ & $(0.074)$ \\
\hline Log(DISTANCE) & $-2.782^{* * *}$ & $-2.849^{* * *}$ & $-1.899^{* * *}$ & $-3.505^{* * *}$ \\
& $(0.279)$ & $(0.577)$ & $(0.681)$ & $(0.700)$ \\
\hline Log(GDPpartner) & $3.136^{* * *}$ & $3.175^{* * *}$ & $2.485^{* * *}$ & $4.431^{* * *}$ \\
& $(0.275)$ & $(0.575)$ & $(0.678)$ & $(0.697)$ \\
\hline Log(GDPUK) & $-9.135^{* * *}$ & $-10.148^{* * *}$ & $-7.574^{* * *}$ & $-14.023^{* * *}$ \\
& $(0.836)$ & $(1.867)$ & $(2.286)$ & $(2.432)$ \\
\hline Log(GDPpercapita, parner) & $0.478^{* * *}$ & $0.671^{* * *}$ & $0.571^{* * *}$ & $0.283^{* * *}$ \\
& $(0.053)$ & $(0.070)$ & $(0.085)$ & $(0.123)$ \\
\hline Log (GDPpercapita UK) & $8.212^{* * *}$ & $9.304^{* * *}$ & $7.103^{* * *}$ & $13.967^{* * *}$ \\
& $(0.635)$ & $(1.444)$ & $(1.860)$ & $(2.185)$ \\
\hline R-square & 0.918 & 0.923 & 0.947 & 0.958 \\
\hline Adjuster R-square & 0.916 & 0.921 & 0.945 & 0.955 \\
\hline
\end{tabular}

Note: Numbers given in parenthesis are corresponding standard deviations. $* * *: p<0.01$; $* *: p<0.05 ; *: p<0.1$

\section{Source: Authors' calculations}

The analysis of the results obtained from the model of the influence of the two dummy variables over UK's export expose the main achievement of this paper. We acknowledge that the coefficient measuring the influence of free trade agreements signed between UK and its' trading partners is statistically significant with a positive sign and an almost constant value. As for the coefficient measuring the influence of UK's membership in the European Union on the country's export, we notice different results. The coefficient is positive throughout the time period yet gradually declines in the third and fourth time period. The coefficient decreases as we shorten the time periods, proving that the average trade advantage due to EU membership has diminished over time. According to the economic theory of regional integration, it was expected that the coefficient will increase due to the many new rounds of enlargement, especially the biggest one in 2004, as well as due to the introduction of the Euro. This can be an indicator of slower economic growth in the EU and decreased demand in EU countries for import. 
On the contrary, as we shorten the time periods, we obtained a coefficient with a similar value for the free trade agreement variable. This confirms that trade exchange within FTA has a significantly higher effect on trade of the United Kingdom in comparison with trade within the EU. However, after UK's withdrawal most of the preferential treatment with third countries will be lost. Therefore, although the United Kingdom-EU Trade Agreement is essential for sustaining the access to the EU's internal Market, the UK will have to actively engage in the realization of preferential agreements that will increase Britain's growth prospects.

\section{Conclusion}

The purpose of this paper was to analyze the influence of EU membership on United Kingdom's prospects for export. We applied the traditional workhorse for international trade, the gravity model for a period of seventy years - from 1973-2020 - and the results have reaffirmed some of the classical and expected findings. Export tends to increase when trading with countries with a higher GDP and tends to decrease when distance increases. The results have also shown that the free trade agreements that the United Kingdom has signed during this seventy years' time period have a positive and significant influence over UK's export. What was unexpected were the results obtained from the influence of EU membership over UK's export. The results have shown that only in the early years EU membership had a favorable and positive influence over UK's export. In the period after 1990 the effect of EU membership over UK's export appears to have decreased over time. This shows that the UK's decision to leave the European Union may have been appropriate, considering that the expected trade creation effect of regional economic integration appears to have become negative for the UK over time. Nevertheless, the most important trading partners of the United Kingdom are countries from the EU. Among the UK's top 10 trading partners, seven are countries from EU - Germany, France, Netherlands, Belgium, Italy, Spain and Ireland (Database 2019).

What is more important to analyze from today's perspective is probably how the UK's foreign trade policy will look like in the future? Even though the results indicate that free trade agreements have had positive influence on UK's export, the question is whether the UK will manage to sign and implement favorable free trade agreements with its trading partners in the future. We are aware that the trade agreement between the United Kingdom and the European Union is signed yet we do not know yet how its implementation will impact UK's trade and whether it will have a positive effect or not. We are also not aware of the trade relations between UK and the USA, or with its' other important trading partners. The question becomes even more unclear as the perspective of analysis will change, given that the UK is no longer member of the European Union. These are all questions that need to be addressed in future and should provide a good basis for future research in this area. 


\section{References}

Anderson, J. E. and Wincoop, E. V. (2003). "Gravity with gravitas: A solution to the border puzzle." In: American economic review 93, no. 1/2003, pp. 170-192.

Almog, A., Bird, R. and Garlaschelli, D. (2019). "Enhanced gravity model of trade: reconciling macroeconomic and network models". In: Frontiers in Physics, 7, p.55.

Berthou, A., Haincourt, S., de la Serve, M., Estrada, A., Roth, M.A. and Kadow, A. (2019).

"Assessing the macroeconomic impact of Brexit through trade and migration channels". In: Occasional Papers 1911, Banco de España.

Bergstrand, J.H., (1985). The gravity equation in international trade: some microeconomic foundations and empirical evidence. The review of economics and statistics, pp.474-481.

Bisciari, P. (2019). "A Survey of the Long-Term Impact of Brexit on the UK and the EU27 Economies". Working Paper Research, 366, National Bank of Belgium.

Campos, R. and Timini, J. (2019). "An Estimation of the Effects of Brexit on Trade and Migration". In: Banco de Espana Occasional Paper No. 1912.

Cappariello, R., Franco-Bedoya, S., Gunnella, V. and Ottaviano, G. (2020). "Rising protectionism and global value chains: quantifying the general equilibrium effects". Working Paper Series, No 2360, ECB.

Dhingra, S., Huang, H., Ottaviano, G., Pessoa, J. P., Sampson, T. and Van Reenen, J. (2017).

"The Costs and Benefits of Leaving the EU: Trade Effects". CEP Discussion Paper, 1478.

Gudgin, G., Coutts, K., Gibson, N. and Buchanan, J. (2017). "The Role of Gravity Models in Estimating the Economic Impact of Brexit". Working Papers, WP490, Centre for Business Research, University of Cambridge.

Helpman, E., Melitz, M. and Rubinstein, Y. (2008). “Estimating trade flows: Trading partners and trading volumes". In: The quarterly journal of economics, 123(2), pp. 441-487.

IMF (2016). "United Kingdom: Selected Issues". IMF Country Report no.16/169.

Kierzenkowski, R., Pain, N., Rusticelli, E. and Zwart, S. (2016). "The Economic Consequences of Brexit: A Taxing Decision". OECD Economic Policy Paper 16.

Mulabdic, A., Osnago, A. and Ruta, M. (2017). "Deep Integration and UK-EU Trade Relations". World Bank Policy Research Working Paper No. 7947

OEC (2019). Country Profile. [Online]. Available at: https://oec.world/en/profile/country/ gbr

Pisani, M. and Caffarelli, F. V. (2018). "What will Brexit mean for the British and euroarea economies? A model-based assessment of trade regimes". Temi di discussione (Economic working papers) 1163, Bank of Italy, Economic Research and International Relations Area.

Tinbergen, J. (1962) "Shaping the world economy; suggestions for an international economic policy." [Online]. Available at: https://repub.eur.nl/pub/16826/Appendices.pdf (last visited May 2021).

Vandenbussche, H., Connell, W. and Simons, W. (2017). "Global Value Chains, Trade Shocks and Jobs: An Application to Brexit". CEPR Discussion Papers, 12303. 